Aoun, M., Mubarak, S., \& Hasnan, N. (2020). The Efect Of Conflict Management Styles On Employee Performance Among Lebanese Industrial Firms. Journal Of Technology And Operations Management, 15(1), 50-59. https://doi.org/10.32890/jtom2020.15.1.4

\title{
THE EFECT OF CONFLICT MANAGEMENT STYLES ON EMPLOYEE PERFORMANCE AMONG LEBANESE INDUSTRIAL FIRMS
}

\author{
${ }^{1}$ Malak Aoun, ${ }^{2}$ Sukaina Mubarak, \& Norlena Hasnan ${ }^{3}$ \\ ${ }^{1,2}$ Lebanese International University, School of Business, Lebanon, \\ ${ }^{3}$ Universiti Utara Malaysia Kuala Lumpur. \\ Corresponding author: malak.aoun@liu.edu.lb
}

Received: 15/1/2020 Revised: 2/2/2020 Accepted: 15/4/2020 Published: 29/7/2020

\begin{abstract}
This paper studies the effect of conflict management on employees' performance among some industrial firms in Lebanon. First, conceptual framework was developed based on extensive literature review where conflict management styles and employee performance were discussed comprehensively in terms of definitions and related previous studies. Due to the lack of empirical studies in the Lebanese industrial sector, this empirical study was conducted to test the proposed research hypotheses. Thus, a quantitative approach was adopted through conducting an online survey among 93 employees from three different industrial organizations specialized in producing construction materials, plastics, and wood and metal furniture in Lebanon. The response rate was limited due to COVID-19 Pandemic, where only 63 employees responded. Data analysis was conducted through SPSS. Descriptive statistics were obtained and research hypotheses were tested using Pearson correlation and regression analysis. The results obtained showed that in general, conflict management has positive and significant effect on employees' performance but to a weak extent. Particularly, only collaborative, compromising and accommodating styles had weak positive correlation with employee performance. Future surveys may involve more companies on a larger geographical scale, and include additional number of workers, for the purpose of attaining more reliable results.
\end{abstract}

Keywords: Conflict management styles, employee performance, Lebanon 


\section{INTRODUCTION}

Human capital is considered one of the vital assets for any organization. The individual's value develops overtime as the employees improve their knowledge, skills and experience, unlike other resources with value that depreciates after a period of time. The prime objective of a successful corporation is increasing revenues, surviving in the industry, and guaranteeing staff reliability, which is an effective route to a successful performance management system. To ensure that employees are operating at their best, it is essential to provide a healthy environment with minimum conflicts in the workplace. People usually view conflict as a difference in opinions among individuals or groups, and it is considered as resentment, antagonistic or hostile. This usually occurs due to disagreement between two parties, in order to achieve different objectives. The diverse beliefs and values are have led to many conflicts at times. Conflict is an intricate, frequent social phenomenon that occurs and takes place in an organization. The deficiency in conflict management expertise will disrupt the organizational goals. In spite of the progress in the conflict management strategies aspect, various establishments remain unable to work through them (Adler, 2008). Even with the countless studies prepared about conflict management in the business field, the degree to which conflicts affects employees' performance in a firm continues to exist (Wanyonyi, 2015). Therefore, the outcomes of this paper will answer the following questions:

RQ1: Is there a relation between conflict management and employee performance?

RQ2: To which extent does conflict management affect employee performance?

To answer these research questions, the following key objectives should be achieved:

RO1: Determine the relationship between conflict management and employee performance.

RO2. Examine to which extent conflict management affects employee's performance.

RO3. Recognize which styles of conflict management are most implemented in the industrial firms.

\section{OVERVIEW OF THE INDUSTRIAL SECTOR IN LEBANON}

The latest report from the Lebanese Ministry of industry shows that about $75.9 \%$ of jobs in Lebanon were found in services, $20.5 \%$ in industry and $3.6 \%$ in agriculture. The largest branch $(19.9 \%)$ of employment was in wholesale and retail trade (including repair of motor vehicles), followed by manufacturing (10.9\%), and (9.9\%) public administration and defense (CAS, 2020). As shown in Table 1, Lebanese Manufacturing businesses seem to be geographically focused. More than the $55 \%$ of the registered industrial corporations are established in both Mount Lebanon and Beirut districts. Besides, the average number of workers per establishment is 21 (Ministry of Industry, 2007). 


\section{Table 1.}

The geographical distribution of number of establishments and the average number of workers/establishment

\begin{tabular}{|c|c|c|c|c|c|c|c|}
\hline Governorate & Beirut & $\begin{array}{l}\text { Mount } \\
\text { Lebanon }\end{array}$ & $\begin{array}{l}\text { North } \\
\text { Lebanon }\end{array}$ & Bekaa & $\begin{array}{l}\text { South } \\
\text { Lebanon }\end{array}$ & Nabatieh & Total \\
\hline $\begin{array}{l}\text { Number of } \\
\text { establishments }\end{array}$ & 239 & 2010 & 518 & 744 & 420 & 102 & 4033 \\
\hline$\%$ of total & 5.9 & 49.8 & 12.8 & 18.4 & 10.4 & 2.5 & 100 \\
\hline $\begin{array}{l}\text { Average } \\
\text { number of } \\
\text { workers per } \\
\text { establishment }\end{array}$ & 19 & 25 & 17 & 18 & 12 & 12 & 21 \\
\hline
\end{tabular}

\section{Conflict Management Styles}

Flanagan and Ruden (2008) stated that in a business unit there are two main types of conflicts known as "task conflict" and "relationship conflict". The task conflict is triggered by contrasts in points of view, opinions, and mindsets. Scientists learnt that disagreements will lead to creativeness and enhanced decision making methods. It is a point of view that recognizes conflict as a constructive factor. The other type is identified as "relationship conflict", like arguments concerning beliefs, private or personal standards, or subjective issues. It is known as a destructive kind of relationship. There is a reason why it is referred to in negative terms, and that is because people are in relationship conflict. Researches have shown this kind of relationship reduces production, drive, and efficiency among the workforce (Awad et al., 2005; Katz, 2007). During a conflict between superiors and subordinates, the staff believes that their managers expect little from them, so they tend to evade the situation through "avoiding style". Supervisors, managers, and employers, those in leadership positions need to practice various sorts of "conflict management styles" while dealing with diverse kinds of employees, subordinate, or group members. Rahim (2011) proposed five scopes that represent the impulsive reaction for different personalities in a disagreement. Rahim's five styles of conflict handling model is founded on "the grid of managerial styles" presented by Mouton and Blake, and "the Thomas's five modes model".

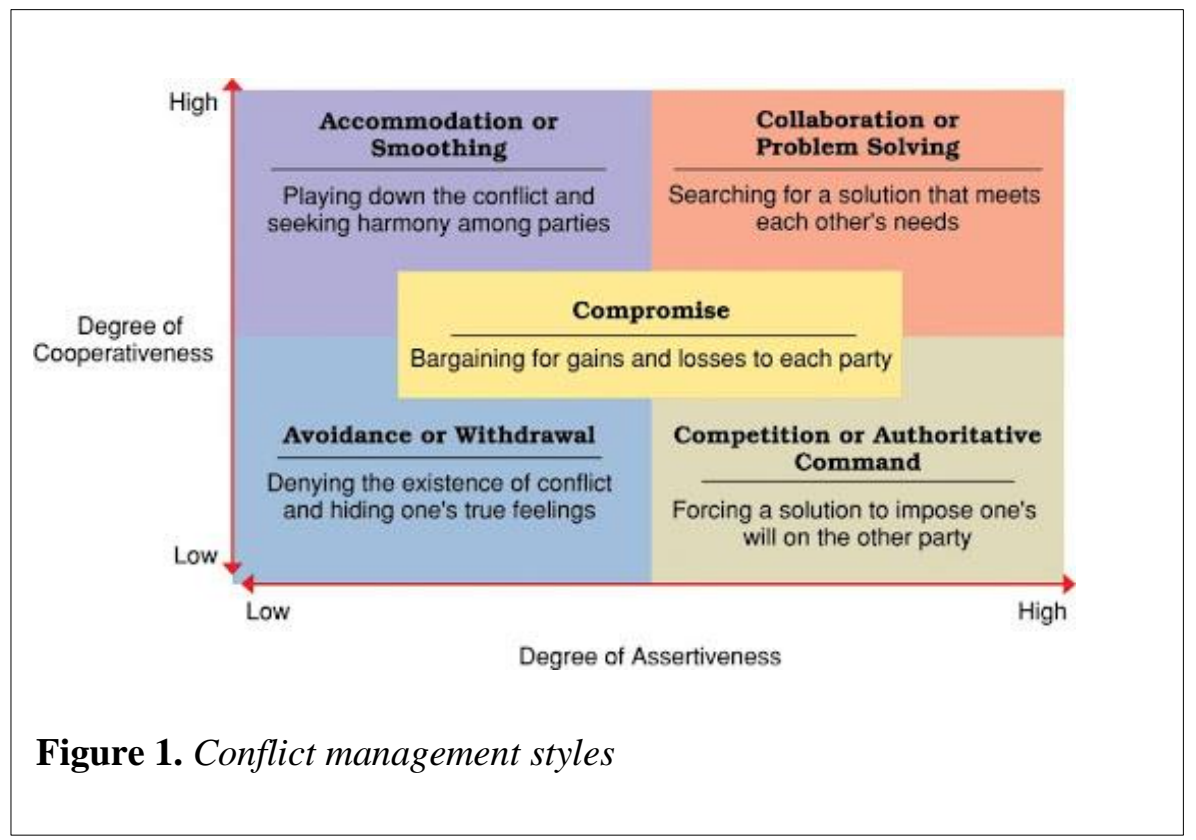


In reference to Wanyonyi et al., (2015), every conflict style has its advantages and disadvantages as shown in Figure 2 below. Practical experiences have shown that "managers cannot be left out of conflicts, but must take active part in it. Of the five conflict management styles, only three were found to correlate significantly and thus predict the variation in organizational commitment which are integrating, obliging and compromising styles. It is recommended that human resources departments should take responsibility to continuously develop employees' interpersonal skills and knowledge in managing conflict. It can be implemented by improving employees understanding on the strength and weaknesses of the five styles of managing conflict and work towards the appropriate use depending on the situation. In addition, employees' perception on conflict should also be improved".

\section{Table 2.}

Advantages and disadvantages of conflict management style

\begin{tabular}{|c|c|}
\hline Style & Advantages \\
\hline Avoidance & $\begin{array}{l}\text { Can maintain the relationship between Does not resolve conflict } \\
\text { managers and subordinates } \\
\text { Using this style will hurt relationship of team. People usually let the conflict } \\
\text { be die down over time }\end{array}$ \\
\hline Compromising & $\begin{array}{l}\text { Can resolve in short time while the Usually starts other isssues } \\
\text { relationship maintain } \\
\text { If people overuse this style, it may cause the people being greedy and ask for } \\
\text { several time to get achieve their desires }\end{array}$ \\
\hline Collaborating & $\begin{array}{l}\begin{array}{l}\text { Makes all parties happy with final } \\
\text { decision }\end{array} \\
\begin{array}{l}\text { Takes longer time and needs more } \\
\text { effort than other style }\end{array}\end{array}$ \\
\hline Forcing & $\begin{array}{l}\text { Better organization decisions will be Aggressions and anger occurs } \\
\text { chosen if the forcer is correct rather than towards its users } \\
\text { choosing less effective decision } \\
\text { Forcing is negative conflict management style that would decrease team } \\
\text { performance }\end{array}$ \\
\hline Accommodating & $\begin{array}{l}\text { Relationship is maintained by the users } \begin{array}{l}\text { The more effective ideas may not } \\
\text { be used }\end{array} \\
\text { Misuse of this style may lead to loss of relationship }\end{array}$ \\
\hline
\end{tabular}

\section{Employee performance}

Employee performance "is the result or level of success of an employee as a whole within a certain period of time in performing the task compared to other things, such as the standard of work, target or criteria that have been determined beforehand and mutually agreed upon" (Maseleno, 2018). It is an employee or a team in an establishment, compared with what is required and what they are responsible for, according to the standards and principles, attain the tasks that are. Performance at work is commonly about whether an employee executes their task right or not. Worker's performance is evaluated through assessments of job performance. Empowering employees is an incentive, in addition to making an employee feel more confident in a workplace. In reference to Allen and Grisaffe (2001), faithfulness exists as a mental state, it also links the worker with the establishment he/she is in, and that any decision taken will affect them and the organization (Balouch \& Hassan, 2014). 


\section{Relationship between conflict management styles and employee performance}

After reviewing some previous studies, it was realized that the workforce should have openness and guide their resources toward achieving the aims and targets desired by the organization. Some suggests that some conflicts are higher on the aggression side, and is implemented by people who intentionally behave in a competitive way as a way of preventing others of accomplishing their personal objectives. And it seems that this is the better and common technique to manage a conflict (Schmidt \& Kochan, 1972).

Another research studies conflicts in a more comprehensive manner, and so, looks at its causes and ways of management in a more general way. Pondy (1967) states by his explanation about conflict," individuals who are involved in a conflict situation must have some sort of preconceived notion as to which mode of conflict handling will be adopted". His explanation permits a wider outlook on "conflict management" that shows wider approaches of handling conflicts opposing the competition approach. Granted, both methods are right if used correctly (Zia \& Syed, 2013). In regards of the "public sector", an experiment was conducted by Havenga and Visagie (2005) expresses that identifying the sources of conflicts and styles of approaching them by the managerial levels is crucial, since it might improve the management style and establish an effective practice in the domain (Human interactions, feelings, socializing must be taken into consideration too. It is argued that through utilizing these findings, opportunity for applying general conflict management strategy in municipal work environment is now more valid. Based on the previous discussion, the following research framework is developed as shown in figure 2 .

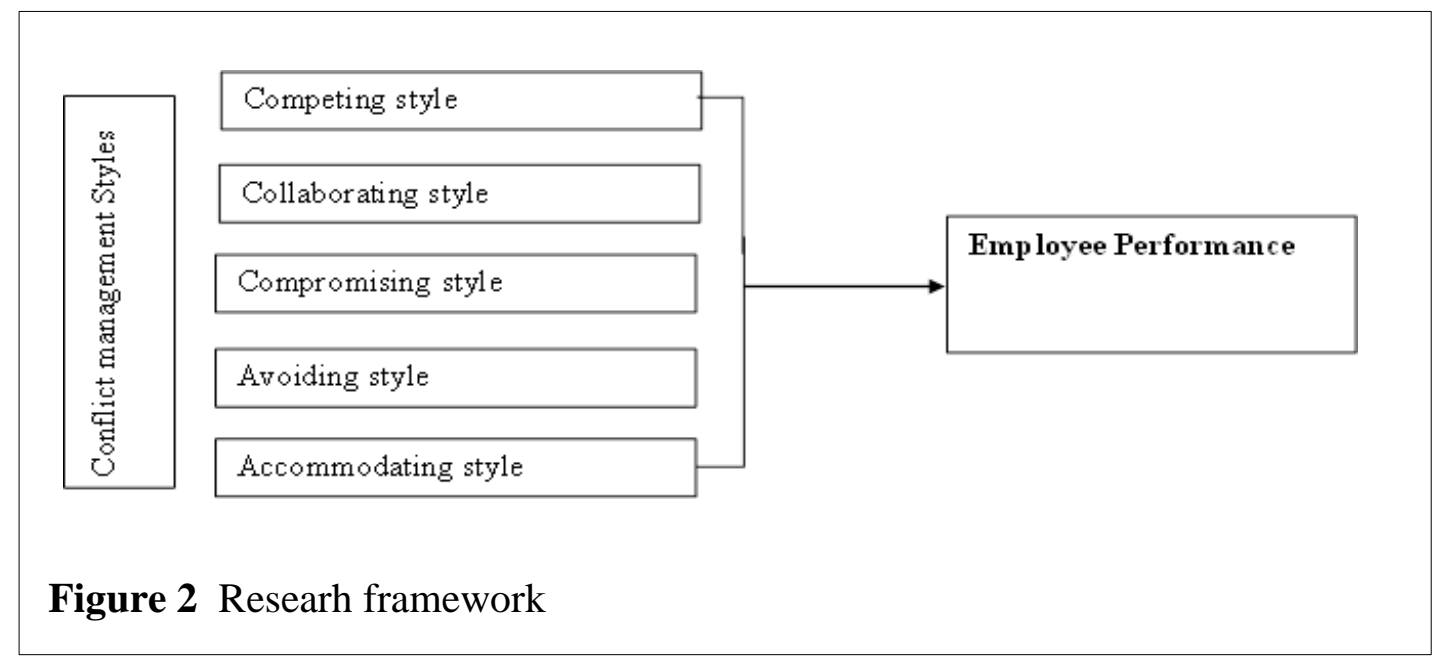

\section{RESEARCH METHODOLGY}

A quantitative approach was implemented to achieve the research objectives. The main objective is to determine the relationship between conflict management styles and employees performance among industrial firms in Lebanon. Based on a postivisim research philosphy, the following hypotheses are proposed: 
H1: There is a positve and significant relationship between conflict management and employees performance.

Ha: There is a positive and significant relationship between "competing conflict management style" and performance of employee.

$\mathrm{Hb}$ : There is a positive and significant relationship between "collaborating conflict management style" and performance of employee.

Hc: There is a positive and significant relationship between "compromising conflict management style" and performance of employee.

$\mathrm{Hd}$ : There is a positive and significant relationship between "avoiding conflict management style" and performance of employee.

He: There is a positive and significant relationship between "accommodating conflict management style" and performance of employee.

$\mathrm{H} 2$ : Conflict management has a positive and significant effect on employee performance.

To test the research hypotheses, an online survey was conducted among industrial firms in South Lebanon. Due to COVID- 19 pandemic, it was difficult identify a large sample frame, thus the research involved three different firms specialized in producing construction materials, plastics, wood and metal furniture in Lebanon. The total number of employees among these organizations is 93. Online questionnaire was prepared on (KoBoToolbox.org) that includes 10 questions to measure the independent variable "conflict management styles" and 10 questions to measure the dependent variable "employee performance" based on 5-Likert Scale. The online questionnaires were distributed randomly among the employees and only 63 responded.

\section{DATA ANALYSIS \& FINDINGS}

First, primary data collected was analyzed using SPSS software. The data is valid based on Factor analysis, where KMO values for the independent variable (0.553) and dependent variable (0.713) are both above 0.5. In addition, Bartlett's test of sphericity implies significance by " $p<$ 0.05". Moreover, the data is reliable since the Cronbach's Alpha value is $(0.745)$ for the all the 18 statements $(0.689$ for the 10 items of conflict management styles and 0.640 for the 8 items of employee performance).

As for the descriptive statistics, the responses ranged between 2.68 and 4.22. The average mean of conflict management styles is (3.51) and (3.92) for employee performance. As for the demographic characteristics, $54 \%$ of respondents were males, $48 \%$ aged between $28-37$ years, $59 \%$ have bachelors degree of education. As for the occupation, $46 \%$ of respondents work in administration jobs, $61 \%$ with a full time contract and $49 \%$ have salaries between one and 2 million Lebanese Lira.

To test the hypotheses, Correlation test was conducted and results are shown in Table 3.

The results show that in general, conflict management has a weak, positive and significant relationship with employee performance with $r=0.373 \& p<0.005$. But particularly, collaborating style has the highest correlation with employee performance $r=3.23$, then compromising style with $\mathrm{r}=3.05$, then accommodating style with a very weak relationship $\mathrm{r}=$ 2.97. Therefore, $\mathrm{H} 1, \mathrm{Hb}, \mathrm{Hc}$, and $\mathrm{Hd}$ are accepted. 
Table 3.

Pearson Correlation Coefficient Results

Correlations

\begin{tabular}{|c|c|c|c|c|c|c|c|c|}
\hline & & AverIV & AverDV & AvCompeting & AvCollaborating & AvCompromising & AvAvoiding & AvAccomodating \\
\hline \multirow[t]{3}{*}{ AverIV } & $\begin{array}{l}\text { Pearson } \\
\text { Correlation }\end{array}$ & 1 & $.373^{* *}$ & $.553^{* *}$ & $.526^{* *}$ & $.537^{* *}$ & $.627^{* *}$ & $.712^{* *}$ \\
\hline & Sig. (2-tailed) & & .003 & .000 & .000 & .000 & .000 & .000 \\
\hline & $\mathrm{N}$ & 63 & 63 & 63 & 63 & 63 & 63 & 63 \\
\hline \multirow[t]{3}{*}{ AverDV } & $\begin{array}{l}\text { Pearson } \\
\text { Correlation }\end{array}$ & $.373^{* *}$ & 1 & .225 & $.323^{* *}$ & $.305^{*}$ & .041 & $.297^{*}$ \\
\hline & Sig. (2-tailed) & .003 & & .076 & .010 & .015 & .747 & .018 \\
\hline & $\mathrm{N}$ & 63 & 63 & 63 & 63 & 63 & 63 & 63 \\
\hline \multirow[t]{3}{*}{ AvCompeting } & $\begin{array}{l}\text { Pearson } \\
\text { Correlation }\end{array}$ & $.553^{* *}$ & .225 & 1 & .170 & .057 & .102 & $.259^{*}$ \\
\hline & Sig. (2-tailed) & .000 & .076 & & .184 & .657 & .428 & .041 \\
\hline & $\mathrm{N}$ & 63 & 63 & 63 & 63 & 63 & 63 & 63 \\
\hline \multirow[t]{3}{*}{ AvCollaborating } & $\begin{array}{l}\text { Pearson } \\
\text { Correlation }\end{array}$ & $.526^{* *}$ & $.323^{* *}$ & .170 & 1 & $.373^{* *}$ & .053 & .215 \\
\hline & Sig. (2-tailed) & .000 & .010 & .184 & & .003 & .680 & .090 \\
\hline & $\mathrm{N}$ & 63 & 63 & 63 & 63 & 63 & 63 & 63 \\
\hline \multirow[t]{3}{*}{ AvCompromising } & $\begin{array}{l}\text { Pearson } \\
\text { Correlation }\end{array}$ & $.537^{* *}$ & $.305^{*}$ & .057 & $.373^{* *}$ & 1 & .150 & .230 \\
\hline & Sig. (2-tailed) & .000 & .015 & .657 & .003 & & .242 & .070 \\
\hline & $\mathrm{N}$ & 63 & 63 & 63 & 63 & 63 & 63 & 63 \\
\hline \multirow[t]{3}{*}{ AvAvoiding } & $\begin{array}{l}\text { Pearson } \\
\text { Correlation }\end{array}$ & $.627^{* *}$ & .041 & .102 & .053 & .150 & 1 & $.337^{* *}$ \\
\hline & Sig. (2-tailed) & .000 & .747 & .428 & .680 & .242 & & .007 \\
\hline & $\mathrm{N}$ & 63 & 63 & 63 & 63 & 63 & 63 & 63 \\
\hline \multirow[t]{3}{*}{ AvAccomodating } & $\begin{array}{l}\text { Pearson } \\
\text { Correlation }\end{array}$ & $.712^{* *}$ & $.297^{*}$ & $.259^{*}$ & .215 & .230 & $.337^{* *}$ & 1 \\
\hline & Sig. (2-tailed) & .000 & .018 & .041 & .090 & .070 & .007 & \\
\hline & $\mathrm{N}$ & 63 & 63 & 63 & 63 & 63 & 63 & 63 \\
\hline
\end{tabular}

**. Correlation is significant at the 0.01 level (2-tailed).

*. Correlation is significant at the 0.05 level (2-tailed).

To test the effect of conflict management on employee performance, regression analysis is used and results are shown in Table 4 According to Frost (2013), R-squared "is always between 0 and $100 \%$. A zero percentage indicates that the model explains none of the variability of the response data around its mean. While $100 \%$ indicates that, the model explains all the variability of the response data around its mean. In general, the higher the R-squared, the better the model fits the data". Referring to the "Model Summary", it appears that the conflict management explains $13.9 \%$ of the variability of employee performance, which is considered as a low effect. Referring to ANOVA results, conflict management significantly can expect the employee performance with $\mathrm{F}(1,61)=9.879$ and $\mathrm{p}<0.01$. Therefore, regression model is appropriate to fit the data of this study. 
Table 4.

Regression analysis results

\begin{tabular}{l}
\begin{tabular}{|l|r|r|r|r|}
\hline Model & R & R Square & $\begin{array}{c}\text { Adjusted R } \\
\text { Square }\end{array}$ & $\begin{array}{l}\text { Std. Error of the } \\
\text { Estimate }\end{array}$ \\
\hline 1 & $.373^{\mathrm{a}}$ & .139 & .125 & .425 \\
\hline
\end{tabular} \\
\hline
\end{tabular}

ANOVA $^{\text {b }}$

\begin{tabular}{|ll|r|r|r|r|r|}
\hline Model & & Sum of Squares & df & Mean Square & F & Sig. \\
\hline 1 & Regression & 1.783 & 1 & 1.783 & 9.879 & $.003^{\mathrm{a}}$ \\
& Residual & 11.011 & 61 & .181 & & \\
& Total & 12.795 & 62 & & & \\
\hline
\end{tabular}

a. Predictors: (Constant), AverIV

b. Dependent Variable: AverDV

\section{CONCLUSION}

In conclusion, the main objectives of this research have been achieved. A positive, significant, but weak relationship between conflict management and employee performance is realized. Particularly, the collaborating and compromising styles are the most implemented styles in the industrial firms, which means that high levels of cooperativeness and assertiveness are executed. However, the extent to which conflict management affects employee's performance was very low. Confidently, the COVID-19 pandemic has influenced this study from different perspectives, thus future studies can expand the empirical study in terms of sample size, sectors, methodology, and analytical techniques.

\section{ACKNOWLEDGMENT}

This research received no specific grant from any funding agency in the public, commercial, or not-forprofit sectors.

\section{REFERENCES}

Agwu, M. O. (2013). conflict management and employees performance in Julius berger Nigeria PLC. Bonny Island. International Journal of Academic Research in Management (IJARM) Vol, 2, 125-139. 
Aminudin, N., Sundari, E., Shankar, K., Deepalakshmi, P., Fauzi, R. I., \& Maseleno, A. (2018). Weighted Product and Its Application to Measure Employee Performance. International Journal of Engineering \& Technology, 7(2.26), 102-108.

Badreddine, Z., \& Aoun, M. (2019). Performance Appraisal Systems in Hiram Hospital and its Relationship with Employees' Performance: Empirical Study. Journal of Business and Social Review in Emerging Economies, 5(2), 275-286.

Bahari, S. F. (2010). Qualitative versus quantitative research strategies: contrasting epistemological and ontological assumptions. Sains Humanika, 52(1).

Baillien, E., \& De Witte, H. (2009). The relationship between the occurrence of conflicts in the work unit, the conflict management styles in the work unit and workplace bullying. Psychologica Belgica, 49(4), 207.

Balouch, R., \& Hassan, F. (2014). Determinants of job satisfaction and its impact on employee performance and turnover intentions. International Journal of Learning \& Development, 4(2), 120-140.

Bartlett, M. E. (2009). Workplace incivility and conflict management styles of community college leaders in the nine mega states (Doctoral dissertation). Retrieved from ProQuest Dissertations and Theses database.(Doc No. 3355130).

Dhammika, K. A. S. (2013). Measuring Employees' Performance in the Public Sector in Sri Lanka: Testing of Two Models.

Ezzeddine, R., \& Aoun, M. (2020). The Effect of 5S on Employee Performance: An Empirical Study among Lebanese Hospitals. International Business and Accounting Research Journal, 4(1), 44-50.

Frost, J. (2013). Regression analysis: How do I interpret R-squared and assess the goodnessof-fit. The Minitab Blog, 30.

Havenga, W., \& Visagie, J. (2011). Managing conflict in a South African non-profit organization: An analysis of conflict generating factors and conflict management styles. Journal of International Management Studies, 6(1), 1-12.

Huan, L. J., \& Yazdanifard, R. (2012). The difference of conflict management styles and conflict resolution in workplace. Business \& Entrepreneurship Journal, 1(1), 141155.

Idowu, A. (2017). Effectiveness of performance appraisal system and its effect on employee motivation. Nile Journal of Business and Economics, 3(5), 15-39.

Jha, S., \& Jha, S. (2010). Antecedents of interpersonal conflicts at workplace. Journal of Management \& Public Policy, 1(2), 75-80.

Kazan, H., \& Gumus, S. (2013). Measurement of employees' performance: A state bank application. International Review of Management and Business Research, 2(2).

Lussier, R.N. (2010). Human relations in organizations: Applications and skill building. Singapore: Mc Graw Hill/Irwin

Mohammed, U. K., Prabhakar, G. P., \& White, G. (2008). Culture and conflict management style of international project managers. International Journal of Business Management, 3(5).

Mwema, N. W., \& Gachunga, H. G. (2014). The influence of performance appraisal on employee productivity in organizations: A case study of selected WHO offices in East Africa. International Journal of Social Sciences and Entrepreneurship, 1(11), 324337.

Olu, O., \& Dupe, A. A. (2008). Impact of conflict management on employees' performance in a public sector organization in Nigeria. Department of Business Administration, Faculty of Management Sciences, Osun State University Okuku, Osun State, Nigeria. 
Wanyonyi, B. E., Kimani, C., \& Amuhaya, I. M. (2015). Conflict management styles influencing organizational commitment among Kenya Seed company employees, Kenya. International Journal of Academic Research in Business and Social Sciences, 5(11), 265-277.

Zia, Y. A., \& Syed, P. H. (2013). An Exploratory Study into the Causes of Conflict and the Effect of Conflict Management Style on Outcome in a Competitive Workplace. Journal of Managerial Sciences, 7(2). 